\title{
Towards the Definition of a Tourism Cluster
}

\section{Magdalena Kachniewska*}

\begin{abstract}
The concept of tourism clusters is becoming central within the tourism development planning process and the EU perceives cluster arrangements as the preferred form of introducing innovations in different economic fields, including tourism. The Polish Tourism Organization (POT) is to launch the subprogram aimed at the commercialization of the tourism product and intensification of SMEs' integration processes (vertical and horizontal ones), which shall boost the innovativeness of Polish tourism regions and enterprises. The main purpose of this article is to find rationale for tourism cluster formation in Polish TDAs and to formulate the definition and main attributes of the tourism cluster. The problem of clusters' impact on SMEs' productivity and the destinations competitiveness will be discussed on the basis of economic theory using the case study and the field work method as well as the literature study.

Keywords: tourism cluster, definition, cooperative networks, competitiveness, tourism destination area.
\end{abstract}

\section{Introduction}

Tourism acts as a stimulating factor for economic (hence national) development. As it is, for the large part, responsible for economic growth, balance of payments, employment and regional balances in individual countries and across regions, numerous tourism entities are looking forward to the reinforcement of their potential in tourism development on the local and regional level.

It is worth mentioning that a dual economic structure of tourism has developed over the years. In the light of recent studies on the phenomena of concentration and restructuring, two categories of companies seem to coexist:

- traditional small and medium sized enterprises (SMEs), which seek a second breath, in order to become international and try to adapt their services to the new requirements of domestic and international demand;

\footnotetext{
* Magdalena Kachniewska, Ph.D., Associate Professor at Warsaw School of Economics (SGH), al. Niepodległości 162, 02-554 Warsaw, magdalena.kachniewska@sgh.waw.pl.
} 
- corporate companies which specialize in large-scale tourism, according to strategies of cost rationalization.

Whereas in the target countries or destinations SMEs continue to offer such tourism services as accommodation, catering and leisure time activities, an international travel and tourism industry has gradually emerged in the source countries as part of the globalization process. The Support Programme "Intelligent Development" launched by the Ministry of Regional Development lays the grounds for new projects aimed at innovation, competitiveness, internationalization and intensification of the Polish SMEs' integration processes. Within the tourism industry the most natural way of integration seems to be vertical integration along the tourism value chain as it constitutes the complete offer for a tourist.

The Polish Tourism Organization is to launch the subprogram aimed at the commercialization of the tourism product and intensification of SMEs' integration processes (vertical and horizontal ones), which shall boost the innovativeness of Polish tourism regions and enterprises. There are four groups of possible beneficiaries of the Programme: (a) start-ups - new tourism enterprises declaring their willingness to enter the overseas markets; (b) tourism enterprises with a strong market position (the main criterion for the participation in the support programme constitutes the minimum share of export volume within the volume of sales); (c) tourist clusters, understood as the form of vertical integration around the theme or local product and (d) tourism product consortium, understood as the form of horizontal integration designed for marketing purposes. The two final groups of entities reflect the tremendous effort being done in Poland towards the improvement of tourism destination management.

The destination's competitiveness "is determined by both tourism specific factors and a much wider range of factors that influence the tourism service providers" (Enright and Newton, 2005, p. 340). The competition among tourism destination areas (TDAs) is not centred on the single aspects of the tourist product (environmental resources, transportation, tourism services, hospitality, etc.) but on the tourist destination as an integrated set of tourism facilities and experiences (Medlik, 1995; Buhalis, 2000; Ritchie and Crouch, 2000). The best modality for objectifying the production and supply of tourism products at the level of individual tourism destination, especially the spatially larger ones, are clusters. The formation of tourism clusters seems to be the simplest way to create an organised offering that would objectify a complete tourism product, previously conceived on a marketing basis.

The existence of regional and local tourism organizations (RTO, LTO) in Poland could be the starting point for the tourism cluster initiatives, however there is no consensus about the actual role of RTOs and LTOs in tourism product 
development and innovation reinforcement. The positive performance of some RTOs and LTOs in Poland constitutes good circumstances for future cooperation within the tourism regions while the poor rating of the others disincline to delegate them to coordinate cluster formation.

The main purpose of this article is to find rationale for tourism cluster formation in Polish TDAs, to formulate the definition and main attributes of the tourism cluster and to compare the attributes with the main characteristics of Polish RTOs and LTOs in context of their possible coordinating role within the new tourism clusters. The problem of clusters' impact on SMEs' productivity and the destinations competitiveness will be discussed on the basis of the economic theory.

\section{Research methods}

When formulating the definition of the tourism cluster three main research methods were used, namely - a case study method, literature research and the conducting interviews method. The first one included some examples of tourism clusters existing in Poland ("The Sun of Region" Cluster, "Via Sudetica", and an innovative tourism cluster "The Crystal of Europe").

A literature review (local and international literature review) serves three main purposes, including establishing the need for the research; broadening the horizons of the researcher and the reader; and preventing from conducting research that already exists. The method sharpened and deepened the theoretical framework of the research and helped to familiarise the reader with the latest developments in the area of research in the field of cluster analysis. Its main aim however was to study the definitions of clusters used in previous works with the aim of adopting them for the purpose of a tourism cluster definition and analysis (see more in the next part of the paper).

Last but not least, the conducting interviews method was used - a datacollecting method involving personal visits to respondents, in particular the leaders of 14 Local and Regional Tourism Organizations. The interview was especially useful in providing a general overview of people's thoughts and experiences within the field of regional tourism promotion and cooperation, the leading position of Local and Regional Organizations as well as their ability to function as the tourism cluster.

\section{Literature review}

Arguments in support of clusters of SMEs are quite difficult to find on the grounds of traditional economic theory. Neoclassical theory does not seem to accommodate positive insights on firm cooperation rather than cooperation 
as collusion, while industrial organization literature is basically concerned with market power and the associated monopoly profit.

The positive insight could be found in the transaction cost theory (Williamson, 1975): when opportunism is absent, inter-firm cooperation emerges as the appropriate firm choice (more efficient then unified or even contractual governance). In a similar way Richardson $(1972,2003)$ emphasised that cooperation is the third mode of carrying out economic activities - the other two being the "market" and hierarchy. Richardson (1972) was probably the first one to explain how the degree of intra-firm specialisation within the economy reduces the cost of adjustment to change, emphasising that the economy with small firms is more flexible, thus more efficient at reallocating resources following a change (Richardson, 2001, 2003).

The support for SMEs has been extended during 1990s to encompass support for the creation of linkages and agglomerations of enterprises as a way of creating and maintaining competitive advantage for participating firms and regions. However the potential advantages of clusters vis a vis larger firms dates back to Marshall (1920) and his treatment of the industrial districts, examined as geographically defined (localized) socio-economic systems of production made up of specialized SMEs. Marshall highlighted external economies, cumulative innovation process and collective efficiency as factors conducive to the industrial district's growth. Piore and Sabel (1984, 30-33) enlightened also other attributes:

- highly differentiated range of products and their constant alteration (both: in response to changing market tastes as well as to shape market tastes and create the new markets)

- technology used in various ways and for various products

- balancing competition and cooperation between firms.

Other researchers emphasised knowledge and learning that took place within districts (Malmberg and Maskell, 1997), flows of information, knowledge and innovation as well as the importance of the social capital (Rosenfeld, 1997). Most researchers seem to acknowledge that horizontal or vertical linkages between firms and the existence of collocated sectors are important contributing factors to firm regional competitiveness and productivity (Porter 1990, pp. 69-89, 1998, pp. 70-90, Inkpen and Tsang, 2005, pp. 146-165).

Penrose effects of knowledge and experience (Penrose, 1959) may apply to cooperating firms and clusters as well. Cooperation may enhance individual firms' productive opportunities, thus enhancing the whole economy's productive opportunity. Some arguments could also be found in Prahalad and Hamel's (1990) core competence theory which suggests the firm should concentrate on its unique competencies looking for the other 
ones within the cooperation network. The resource-based theory, combined with the institutional approach, opens the way towards the model of interorganizational competitive advantage based on relationships (Oliver, 1997). The last one enables the firm to embody the new, so far neglected sources of competitiveness possessed by other entities within the cooperation network (Kachniewska, 2009, pp. 49-50) as well as to gain the so-called "relationship ratio" (Dyer, Singh, 1998).

In 1990, Porter proposed the concept of "industrial clusters" (Porter, 1990). The rationale for clusters theory development (as well as other cooperation network) are market failures (market imperfections), government failures and systemic failures (low social capital, high cost of cooperation with R\&D institutions, low level of education etc.).

As in the competence-based theory firms are defined as bundles of competencies, social systems can also be defined as bundles of competencies. Hence Lawson's (1999) competence theory of the region constitutes an attempt to bring together the insights of Marshallian industrial districts literature, economic geography and resource-based approach. Special emphasis was given to interaction taking place within the cluster and linkages with smaller units of the cluster (firms, public agencies).

As an economic phenomenon and the mode of economic development, the industrial cluster has caused widespread concern of scholars. Both concepts: of industrial districts and of manufacturing cluster are grounded in the theory of economic geography, specifically its concepts relating to agglomeration economies, comparative advantage and central place distribution (Isard, 1956; Nourse, 1968). Associated with these works are the writings in regional development (Friedman and Alonso, 1964) and industrial districts (Piore and Sabel, 1984; Harrison, 1992) mentioned above. However "industrial districts are usually local clusters of single product industries, like the fashion district of Manhattan or the leather footwear clusters of Italy, and they have evolved out of shared comparative advantage concepts. In contrast, cluster theory refers to concentrations of interrelated but different industries displaying a shared understanding of the competitive business ethic emanating from competitive theory" (Jackson and Murphy, 2002, p. 38).

Porter (1998, pp. 197-198) understood clusters as geographically proximate groups of interconnected companies, specialized suppliers, service providers, firms in related industries and associated institutions (e.g. universities, standards agencies and trade associations) in particular fields that compete but also cooperate". The presence of clusters is based on the fact that actors are located in a geographic context strongly influenced by externalities, mainly positive, that affect productivity. These positive 
externalities emerge through knowledge and workforce agglomerations that connect industries, technologies, skills, and purchased inputs.

In the last two decades cluster policies emerged as a central focus for territorial development decision-making processes. The benefits, especially in terms of collective learning, knowledge sharing and other types of agglomeration economies and spill-over effects, are well stressed in the regional science literature (Cooke, 2001; Torre and Rallet, 2005).

Tourism researchers have been searching for years for an appropriate paradigm to provide the framework for their research and teaching in the area of tourism development. The publication of Hjalager's article in "Tourism and Hospitality Research" (Hjalager, 2000) occurred to be an interesting stimulus for adapting the theory of industrial districts in the tourism context, mainly in understanding success factors for tourism destinations (Hjalager, 2000, p. 208). Hjalager indicated several points of difference but her article opened the way to exploration of the business literature and to formulation of the tourism cluster model. Jackson and Murphy (2002) noted that the cluster model provides a broader framework for analysis than does the industrial district model, which could be regarded as a subset or special case of the Porter model.

Networks have attracted a great deal of attention and have widened the perspective of organising for the development of economic systems such as tourism (Weaver and Opperman, 2000). A number of studies have been conducted on cooperation between companies in different constellations. These studies have principally focused on vertical networks and cooperation between buyers and sellers at different levels of the supply chain, each providing complementary products or services. The cluster concept goes far beyond the supply chain concept, which focuses on an organisation and its customers and suppliers (Carrie, 1999, pp. 45-50). A cluster is a network of companies, their customers and suppliers of all the relevant factors, including materials and components, equipment, training, finance and so on. It extends to educational establishments and research institutes which provide a large part of their human and technological capital. They are all stakeholders in the end market, influenced by globalisation, commercialisation, skills development, inward investment, start-ups and trade development.

Although Porter's original works on ,competitive advantage' (Porter, 1980 and 1990) were mainly focused on manufacturing it was recognised that these works could apply also to service industries such as tourism. Research on the tourism industrial cluster started relatively late, but scholars have made certain achievements after years of researching using the cluster diagram and "Porter diamond model" (Jackson and Murphy, 2002; Yimei, Yulin and Zhigao, 2004; Liu and Yang, 2013). Industrial cluster theory research 
has gradually spread from the initial manufacturing research to the tourism industry.

\section{Tourism product structure - the rationale for tourism clustercreation}

The tourism sector can be viewed as comprising a variety of producers, distributors and facilitators. Whereas in the past the boundaries between the different players in the market were clear, vertical and horizontal integration in the tourism sector has resulted in a blurring of these boundaries (Kachniewska, 2006a, p. 20). Unlike other products offered by manufacturing or service companies, tourism products are heterogeneous: they are complex and consist of plenty of complementary components provided by suppliers from various public and private sectors. The purchase and consumption of the tourism product is spread over time and distance (Kachniewska, 2006a, p. 16). Each tourism organization provides only one or several components of the total tourism product that is consumed during the course of the complete tourism experience. One week stay of a tourist in a distant place entails contacts with some 30-50 different entities (tour operator, insurance company, carrier, hotel, restaurant, tourism attraction, exchange office, taxidriver, souvenir shop, local authorities etc.) - this way a tourist value chain is being constructed. In order to enhance customer satisfaction, tourism companies have to establish effective relationships with their stakeholders, and especially with their suppliers, defined as those entities operating within the external environment that are responsible for the provision of other components of the total tourism product.

Tourists tend to base their judgments on the satisfaction with a vacation experience on all the components of a complex tourism system. These components are captured by the tourism value chain underlying both the production and consumption of holiday experience (Bieger, 1997). Since all services contributing to the holiday experience take place in a tourist destination, tourism researchers accept tourist destinations areas (TDAs) as the relevant unit for competition or benchmarking analyses.

As an economic phenomenon, the tourism industry essentially represents a consolidation of related economic and non-economic entities. "Tourism is the sum of the phenomena and relationships arising from the interaction among tourists, business suppliers, host governments, host communities, origin governments, universities, community colleges and non-governmental organizations, in the process of attracting, transporting, hosting and managing these tourists and other visitors" (Reid, 2003).

The attitude of local people towards tourists also constitutes one of the elements of tourism value chain. Not all the inhabitants participate indirectly 
in tourism prosperity and there is a necessity to find the way to demonstrate the benefits connected with tourism development of the area: higher profits, possible investments beneficial not only to tourists but also to local people, development and increased attractiveness of the area, improvement of the area's beauty and the quality of natural environment etc. (Kachniewska, 2011, p. 56). There is also the necessity to create tourism consciousness of local people (tourism knowledge, the awareness of tourism economics) and to deal with myths and emotions connected with tourism development which seems to be very difficult to fight.

Social and environmental strategies of TDA cannot be properly developed without the public-private partnership. The public sector usually suffers from the lack of funds and inability to take risk while the private sector is unable to form the complex and complete quality offer of the area. Augustyn (1988) gives three reasons of the limited influence of enterprises on the quality offer of the TDA:

- there is a lot of antagonism between what is profitable for different companies, the society and the area as a whole

- the activity of enterprises concentrates on some chosen areas, neglecting the other ones

- the abilities to absorb additional tourists may be limited by the quantity of local tourism resources (especially natural ones).

The cooperation of public and private sectors may help to overcome the gaps and ensure the sustainable tourism development.

The evolvement of nature-based sustainable tourism seems to be another important change affecting the competition process among tourism enterprises and destinations. The lack of environmental awareness as well as high cost of eco-technologies keep the SMEs back from any ecological initiatives and deteriorate the overall image of the destination. Proper management of the natural environment seems to be another difficulty as the development of tourism industry could become one of the most devastating factors (at least causing the permanent landscape modifications) deteriorating tourism attraction of the area. Broad service offer of numerous enterprises can become the source of its competitive advantage and at the same time enables the relief of natural environment.

The geographical area is not the business unit in a sense we get used to when analysing the activities of business enterprises. However, the development of TDA's management is of greater importance as this is a place of (Kachniewska, 2004):

- concentration of all the tourism enterprises activities,

- creation of the tourism image,

- branding of tourism product,

- cooperation of the public and private sectors, 
- last but not least - meeting tourists' requirements.

According to such an approach, all the TDA's should be treated as a system of public organizations, private enterprises, local people (social environment), natural environment and other tourist attractions as well as all the relations between them (Kachniewska, 2006a, p. 127).

An inability of an individual tourism firm to offer the total quality tourism product that the customer expects at the beginning of the tourist purchaseconsumption process again leads to the idea of the tourism cluster. A cluster is a way of understanding a business's positioning within a broader context that includes all competing factors and elements that help companies develop a strategy in a particular geographical area. Being part of a cluster means competing and cooperating at the same time: competition puts a positive pressure toward innovation and continuous improvement, while customers receive an integral product resulting from the complementary interaction of cluster elements (Artavia, 2000). A competitive advantage can be gained from a range of sources, including technology, differences in supply, or product differentiation. The companies must concentrate on such activities and on the competence to build sustainable competitive advantages and therefore create a value greater than that of their competitors.

One more argument for the formation of a tourism industry cluster is a low level of SMEs competitiveness. Polish tourism SMEs are quite rarely associated with the potential for increased innovativeness but they still have the positive influence on the elasticity and sustainability of the economy. The European policy interest in SMEs can be explained by considering the advantages associated with small firm size (Piore and Sabel, 1984, Richardson, 2003). High transaction costs and rather poor resource-competence related factors could be balanced by flexibility in the economy, suitability to meet continuously changing demand conditions and wide network of cooperation ties (Kachniewska, 2006b, p. 315).

The consequences of globalization have a very strong impact on the typical SMEs. The international travel and tourism industry is composed mainly of large companies that organise tourism to various destinations on an industrial basis. They offer standardized products and develop global strategies that enable them to make the best use of the local potential worldwide. Although the number of large companies is relatively small in the tourism industry, they account for more than a half of total turnover in the sector and for a significant proportion of employment. The SMEs in traditional TDAs are not ready yet to cooperate with global players in world tourism industry on a wide scale and to form internationally competitive destinations. Large companies, which benefit from standardisation and economies of scale, are in a position to offer their clients more attractive services at very competitive prices. They 
are able to shape new tourism markets and offer new products, which helps them to increase the "customer value" and to reduce their production costs. The consequences for SMEs are dramatic loss in market share and growing financial pressure (Alcouffe and Coulomb, 1993).

Another challenge for small tourism enterprises is the rising role of information technology in tourism. Technological innovations are also having a significant effect on the governance/management of the value chains and are encouraging the development of new tourism business models in a global value chain, notably for distribution chain. The major players have been the main beneficiaries of technological innovation whereas the smaller actors, due to lack of capital, IT literacy, technophobia and, above all, the lack of clear strategic plans, are not always taking real advantage of technological innovation. The properly managed cluster might help to overcome these deficiencies.

The decision to cooperate usually depends on the expected benefits: lower risk related to business activity; economies of scale; lower transaction costs and operating costs; more safety in the turbulent environment; protection from a global competition; offer diversification; additional funds; the diffusion of knowledge and information; more flexibility; lobbying and stronger pressure on local authorities; more effective development; limited seasonality; better access to the unique competence, funds and resources; tax optimization; wider value chain; more local entrepreneurship; enhanced tourism innovativeness (both product and process one).

A huge part of innovations result from the interaction processes (organizational learning and common entrepreneurship) within the groups of entities working together and cooperating. The development of such interdependence has a positive impact on the firms' innovative capabilities. The shift from a single act of innovation towards the complex social mechanism constitutes the basis for new production processes and new model of innovation (the interactive model instead of the linear one).

There are also some demand structures affecting the activity of tourism enterprises and the position of destinations in a global tourism market. Besides pure leisure activities such as swimming, skiing or sunbathing, other types of tourism activity have gained importance, e.g. cultural and naturebased tourism. The enterprises need to adapt to such changes and develop new products. The demographic changes reinforce these trends as the growing share of people over 50 as well as disabled persons increases the demand for more specific products. Health, spa and "keep fit" tourism are likely to be among the segments to benefit particularly from the increasing economic importance of elderly tourists. Those complex tourists' needs are met not just by one product or service but by three elements of the area's 
attractiveness (3As): accessibility, attractions, amenities (Holloway, 1996). The proper management of the TDA includes the recognition of all the factors, products, services which create the overall image of quality destination.

Within the tourism cluster the interested parties from all the value chain segments (hoteliers, tourism operators, restaurant owners, storeowners, museums, etc.) aspire to a common goal - to the development of a competitive tourism industry streamlined toward strategic growth and an added value. Even if an individual company at a destination feels autonomous, it represents just a single component of the total tourist product. The value of the tourist product, both to the customer and provider, emerges when the customer arrives at the production arena, the destination (Grängsjö and Gummesson, 2006, p. 62). Thus, the clustering should be principally connected to an identical spatial capture of a concrete tourism destination.

The co-operation between the providers of tourism services within a tourism cluster should be based on formally established links in order to bring about the benefits of synergy. Since each tourist destination is an agglomeration of businesses each with its own agenda and priorities, it is a difficult industry to coordinate and manage at the destination level. The process of creating a complex tourism product calls for the synergistic action of different economic and non-economic factors that participate in its formation through vertical and horizontal integrations. Bearing that in mind, a cluster seems to be the most obvious form of tourism product development within the tourism destination. No other form of regulation allows the combination of so many different entities of both non-profit and business profile.

\section{Tourism cluster concept - the role of regional and local tourism organisations}

Business ties in tourism take the form of numerous different partnership systems: strategic alliances, joint-ventures, consortia, holdings, coalitions, franchising agreements etc. More and more often the business ties enlarge towards the cooperation with the government, local authorities, local citizens, R\&D institutions as well as business support institutions. The intersector regional and local partnerships are preferred by the EU as the effects of endogenous processes building the consensus between local entities, enabling common strategies and the coordination of activities, the access to the key competencies, promote and create innovations, strengthen the identification of the local players within the local social, culture and natural environment, enhance the competitiveness of the regional and local entrepreneurship.

A tourism cluster is a complex organisation, with a structure made of various systems, each possessing its own, different information infrastructure. 
The members of a cluster, while retaining their legal subjectivity and economic independence, represent a flexible form of economic integration aimed at achieving a common goal.

As tourism destination includes multiple types of actors, the tourismindustry cluster should contain the following trades and local segments: attractions (golf courses, museums/galleries, parks, live entertainment venues and other sites), transportation (airport/air service, charter bus service, public transit), support services (facilities management, public relations, advertising, finance, insurance), lodging, retail shopping, restaurants, specialised training programs as well as local authorities, tourism non-profit organizations, business environment institutions, educational background (universities, $R \& D)$, all of them cooperating with each other within the same tourism brand (regional or local tourism product) and at the same time competing in quality, innovativeness and the uniqueness of the own tourism offer.

The geographical concentration of cluster members lowers the distribution and logistics cost and ensures the access to knowledge and competencies. That is why clusters usually comprise the entities from the relatively small territory. However, the tourism cluster should not be limited to the group of neighbouring entities operating within the TDA. On the contrary, it seems to be natural that a tourism cluster includes enterprises operating in the tourism generating areas (TGA) - in the distance (overseas) markets. It is the direct consequence of the adopted competitive strategy which might be (Porter, 1980) the cost leadership or differentiation strategy combined with the market segmentation (market focus). The main condition of its successful accomplishment is a well-thought-out identification and choice of distribution channels and promotion tools which is determined by the close cooperation with entities representing the TDA in the target market(s). The effectiveness of every tourism cluster is correlated with its ability to identify (or to shape new) target markets delineated in the geographical, economic (income level) and socio-demographical context. This aspect needs to be stressed as the weak position of the Polish tourism regions to some extent results from a very traditional (if not outdated) way of operating: they are multifunction, their boundaries are unclear and opened, strong seasonality of operations, diversified tourism attractiveness and prevailing role of the public sector make them uncompetitive and unable to control their own supply. Indistinctive tourism supply usually goes hand in hand with the inability to identify the most profitable target markets, improper configuration of distribution channels and lack of promotion strategy.

The basic attributes of the tourism cluster comprise (Goetz, 2006, pp. 8-23; Gorynia and Jankowska, 2007, pp. 311-340): 
- space - entities operate within the delimited territory (TDA) positioning their offer on the strictly selected (domestic and overseas) target market

- the number and structure of entities - the critical mass of diversified entities and well developed infrastructure are the basic conditions of tourism cluster success. Diversification concerns the legal form, ownership and profile of business enterprises and other units (nonprofit organizations, local authorities, R\&D, universities) from the overall tourism value chain, competing and cooperating, coordinated by the cluster broker or animator.

- cooperation background - the precondition of clusters foundation and future effectiveness is trust (limited opportunism propensity) as well as specialization, knowledge sharing and information flow (limited transaction costs)

- relations-business and social ties of formal and informal character and high intensity, both cooperative and competitive ones characterised by strong interaction, knowledge and information diffusion.

- foundation rules - the process of cluster's foundation should base on the system approach and open membership

- vision and mission - the common trajectory of development (larger firms catalyse the operations of smaller partners, the entrepreneurship expands towards the non-business entities) and collective procedures directed towards the growth of tourists satisfaction and enhanced competitiveness of the TDA

- benefits - favourable development conditions, multiple and acceleration effects, outstanding competitiveness and innovativeness, economies of scale and synergy, high development dynamics, new business opportunities and the chance to acquire (EU and other) funds.

Local authorities might create potential to the establishment, operation and development of cluster initiatives within the public-private partnership, financing business, communal and technical infrastructure of the TDA.

The foundation process of a tourism cluster should have the continuous nature as only in the longer term the positive effects can be observed: tourism offer specialisation and differentiation; income growth, inspiring local citizens to business activity in tourism or referring industries; stimulation of entrepreneurship and dynamic creation of new business and tourism product innovativeness; job creation and better quality of tourism offer; accumulation of social capital and lower transaction costs; competitive advantage of the TDA and all the cluster members; lower business risk and spread of responsibility; the utilisation of entrepreneurial skills of numerous actors in the region; better communication and the effect of organisational learning. 
The main strategic premise constituting the rationale for cluster-based tourism development is generating positive effects (economies of scale and synergy) for all the TDA (not only the cluster members). It improves the TDA's competitiveness and is the source of the external effects enhancing all the entities and local citizens (greater social and economic activity, braking down the stereotypes and prejudices).

The determinants of successful cluster initiatives include: the prevailing commitment of the private factor; catalytic function of the public institutions (investment policy, promoting innovativeness and entrepreneurship); the lowering public role in the long term; transparent innovation and cluster policy (e.g. financing of common initiatives); wide spread of beneficiaries and effective consultancy and evaluation mechanisms.

There is no one recommended cluster model that would be appropriate in every conditions. In every circumstances an individual set of coordinating and supporting measures should be defined. The formulation of attributes of the tourism cluster should refer to different cluster classifications. Clusters are classified according to:

- the economy sector (manufacturing and service cluster)

- modernity of the industry (modern technologies and traditional industries)

- foundation motives (traditional industries revitalization, modern technologies development, improved/enhanced cooperation ties, virtual cooperation, target-oriented clusters (e.g. clusters founded in order to obtain EU development funds)

- governance system (without any central entity, one central/ coordinating entity)

- the form of cooperation type: formal (societies, limited companies, consortia, cooperative society, foundations) and informal cluster

- the level of awareness (existing clusters, hidden clusters and potential clusters)

- the scope (international, cross-border, national, regional and local clusters)

- the life cycle stage (embryonic, growing, mature, declining)

- the structure of the cluster (Italian type - horizontal ties, Danish model - with so called cluster broker, Dutch cluster - with the central role of R\&D entity, Finnish one - the prevailing position of the local government) (Gorynia M., Jankowska B.2007: pp. 311-340).

The Danish model seems to be the most appropriate in Polish economic and political conditions and Polish tourism position. A so-called broker (or cluster animator) coordinates the process of instituting and member appointment, motivating them to cooperation and creating the cooperative network. The broker's role terminates when the network of different 
entities is arranged and the society or other organization is appointed to continue the coordination of cluster's operations. The Polish practice shows that partnership structures arranged on temporary principles without hierarchized organizational structure tend to be fragile and unstable, incapable to integrate and sustain common initiatives. The awareness of mutual benefits is inconstant and non-evident. In such circumstances the most active and entrepreneurial firms need to overcome the resistance of those reluctant, risk averse and indolent entities. The need to point the most active, leadership units seems to be the indispensable condition of the cluster initiatives in such circumstances (Bordas, 2001, p. 38-41). The coordinating role can be delegated to the local government, public-private partnership or the institution of business environment (local development agency, tourism society or business chamber). The dominance of competitive relations over the inclinations towards cooperation in many tourism regions calls into question the ability to establish a tourism cluster without the broker (leading entity).

The strategic and legislative documents in Poland create favorable conditions to the cluster initiatives. "Directions of tourism development" and "The Polish Marketing Strategy in the Tourism Sector" include the creation of public-private partnership (PPP), the development of tourism and information infrastructure, investment incentives, tourism product innovation stimuli, tourism labour quality improvement, new technologies development, the support of tourism organizations, R\&D for tourism industry, entrepreneurship support, consulting programmes for tourism SMEs, international cooperation etc.

Polish regional and local tourism organization created in line with of The Act on Polish National Organization are accredited to promote tourism regions, support the development of the tourism function in TDA; initialize, give opinions and coordinate the development plans and tourism infrastructure modernization. RTOs and LTOs are supervised by the Ministry of Sport and Tourism. There is no common form of their activity (prevailing form is association) but the operating activities of RTOs and LTOs are to be addressed to all the tourism region (not only to the organization members) in the context of economic, social and environmental development.

However the last decade of RTOs' and LTOs' activity allows us to recognize that although the number of tourism organizations is consistently growing, their activity effectiveness varies from one region to another.

Next to the numerous tourism organizations there are same cluster initiatives in Poland as well, however, these are quite young structures and they constitute an attempt to formalize the existing business ties in the complicated formal, legal and economic conditions and growing 
competitiveness of the tourism market. The majority of Polish clusters refer to the Danish model, however some of them are based on the Dutch model (central position of a research institution).

One of the oldest tourism clusters in Poland is Tourism and Local Development Cluster "The Sun of Region" established in order to imply modern technologies in the tourism sector operation and information development. It associates the enterprises, local authorities and R\&D entities. Another cluster (of cross-border character) named Via Sudetica operates in the southern part of Poland and is constituted around the product of Polish ceramic art of Bolesławiec Region and the most extraordinary tourism attraction concentrated along the historical route in the Sudety Mountains, joining three regions of Poland, Czech Republic and Germany. Another example is the initiative of Opole Region Authorities to create a local tourism cluster "Milk and Honey Land" operating mainly within the agro-tourism sector.

However, among 45 innovative clusters listed within the register of Polish Agency for Enterprise Development only one partnership operates exclusively in the tourism sector, namely North-East innovative tourism cluster "The Crystal of Europe" coordinated by the Science Research and Technological Part East Poland in Suwalki.

The Polish tourism clusters also associate local governments and research institutions as well as universities and business chambers. They concentrate mainly on the implementation of new technologies and local tourism product branding, while quite often they also take care of the new product development and active approach to market shaping.

There is no doubt that Polish RTOs and LTOs are the most common form of tourism regional cooperation, however, they cannot be identified with clusters. Januszewska and Nawrocka (2008) compare the attributes of both forms of cooperation (Table 1). 
Table 1. Similarities and differences between tourism clusters and regional/ local tourism organizations.

\begin{tabular}{|c|c|c|c|}
\hline \multirow{2}{*}{ Attribute } & \multirow{2}{*}{ Similarities } & \multicolumn{2}{|l|}{ Differences } \\
\hline & & Tourism cluster & RTO / LTO \\
\hline Territory & $\begin{array}{l}\text { Both can be limited to } \\
\text { the TDA or any other } \\
\text { territory. }\end{array}$ & $\begin{array}{l}\text { According to the location of } \\
\text { the cluster members it could } \\
\text { be a local, regional, national } \\
\text { or international (cross-border) } \\
\text { cluster. There are also possible } \\
\text { business ties with entities located } \\
\text { in the target market. }\end{array}$ & $\begin{array}{l}\text { The territory of } \\
\text { operations is limited to } \\
\text { the territory of TDA. }\end{array}$ \\
\hline $\begin{array}{l}\text { Creating } \\
\text { process }\end{array}$ & & $\begin{array}{l}\text { Long-term process starting with } \\
\text { independent units up to the tight } \\
\text { cooperation of various entities } \\
\text { and high level social capital. }\end{array}$ & $\begin{array}{l}\text { Membership } \\
\text { declaration. }\end{array}$ \\
\hline Goals & $\begin{array}{l}\text { Widely defined } \\
\text { development of } \\
\text { Tourism product and } \\
\text { Tourism activity }\end{array}$ & $\begin{array}{l}\text { The competitiveness of the } \\
\text { region and innovativeness of the } \\
\text { Tourism product. }\end{array}$ & $\begin{array}{l}\text { The development } \\
\text { of Tourism regional } \\
\text { product and its } \\
\text { promotion. }\end{array}$ \\
\hline Membership & Open access & $\begin{array}{l}\text { Members usually come from } \\
\text { various sectors and industries } \\
\text { (Tourism firms, supporting } \\
\text { services, non-profit entities, } \\
\text { research institutions, universities } \\
\text { and business environment } \\
\text { institutions. }\end{array}$ & $\begin{array}{l}\text { Mainly institutions } \\
\text { operating in the } \\
\text { tourism market. }\end{array}$ \\
\hline $\begin{array}{l}\text { The scope of } \\
\text { entities }\end{array}$ & & $\begin{array}{l}\text { Core business entities (tourism } \\
\text { enterprises) supporting } \\
\text { institutions, hard and soft } \\
\text { infrastructure. }\end{array}$ & $\begin{array}{l}\text { Local government, } \\
\text { Tourism enterprises and } \\
\text { organizations, non- } \\
\text { profit entities (usually } \\
\text { tied to the Tourism } \\
\text { activity). }\end{array}$ \\
\hline $\begin{array}{l}\text { Ownership } \\
\text { structure }\end{array}$ & & Dominance of business entities. & $\begin{array}{l}\text { Dominance of local } \\
\text { authorities. }\end{array}$ \\
\hline $\begin{array}{l}\text { Organizational } \\
\text { form }\end{array}$ & $\begin{array}{l}\text { Both might be non- } \\
\text { profit entities }\end{array}$ & $\begin{array}{l}\text { No recommended form (cluster } \\
\text { can be treated like a business } \\
\text { organization) }\end{array}$ & $\begin{array}{l}\text { The recommended } \\
\text { form is association. }\end{array}$ \\
\hline $\begin{array}{l}\text { Legal } \\
\text { framework }\end{array}$ & & No legal framework. & $\begin{array}{l}\text { Act on the Polish } \\
\text { Tourism Organization }\end{array}$ \\
\hline $\begin{array}{l}\text { Initializing and } \\
\text { coordinating } \\
\text { entity }\end{array}$ & & $\begin{array}{l}\text { Cluster broker: the supporting } \\
\text { entity, industry leader or any } \\
\text { other institution. }\end{array}$ & $\begin{array}{l}\text { Commonly the local } \\
\text { government. }\end{array}$ \\
\hline $\begin{array}{l}\text { The importance } \\
\text { of research } \\
\text { institution }\end{array}$ & & $\begin{array}{l}\text { Indispensable condition of cluster } \\
\text { formation. }\end{array}$ & $\begin{array}{l}\text { Discretionary } \\
\text { condition. }\end{array}$ \\
\hline
\end{tabular}




\begin{tabular}{|c|c|c|c|}
\hline $\begin{array}{l}\text { Source of } \\
\text { financing }\end{array}$ & $\begin{array}{l}\text { Public and private } \\
\text { source of financing }\end{array}$ & & \\
\hline $\begin{array}{l}\text { The importance } \\
\text { of innovations }\end{array}$ & & $\begin{array}{l}\text { As cluster is perceived as the } \\
\text { innovative cooperation net, } \\
\text { innovativeness of entities is of } \\
\text { utmost importance }\end{array}$ & $\begin{array}{l}\text { The issue is not } \\
\text { exposed. }\end{array}$ \\
\hline $\begin{array}{l}\text { Hierarchy } \\
\text { structure }\end{array}$ & $\begin{array}{l}\text { No hierarchy } \\
\text { dependence. }\end{array}$ & & \\
\hline $\begin{array}{l}\text { The role } \\
\text { in tourism } \\
\text { product } \\
\text { development } \\
\text { and branding }\end{array}$ & $\begin{array}{l}\text { Tourism product } \\
\text { development is the } \\
\text { main goal of both } \\
\text { institutions as well as } \\
\text { product branding and } \\
\text { promotion. }\end{array}$ & & \\
\hline Time frame & Long-term activity & & \\
\hline $\begin{array}{l}\text { Development } \\
\text { measures }\end{array}$ & & $\begin{array}{l}\text { Growth of productivity of local } \\
\text { enterprises, innovativeness } \\
\text { enhancement, formation of new } \\
\text { enterprises, job creation. }\end{array}$ & $\begin{array}{l}\text { Increased volume of } \\
\text { tourism flow, tourism } \\
\text { product quality } \\
\text { enhancement. }\end{array}$ \\
\hline
\end{tabular}

Source: Januszewska and Nawrocka, (2008), pp. 291 - 292.

Tourism cluster and RTOs/LTOs, despite some similarities, in many aspects are different and so far they have been perceived in Poland as complementary and interdependent units. Clusters often run production and distribution activities while RTOs/LTOs concentrate on information and promotion activities in domestic and foreign markets. The above mentioned Via Sudetica tourism cluster in Boleslawiec gathers local lodging and catering businesses while the local government initialized the creation of Lower Silesia Tourism Organization, where politics seems to be a very important factor which is not exposed in the cluster (Januszewska and Nawrocka, 2008, p. 293).

According to the theory, the tourism cluster should be aimed at: identification of tourism potential of existing SMEs on the local and regional level; the prediction of new business ties and balance between the cooperative and competitive relations among the cluster members; systematic observation and research of the tourism potential of local enterprises within various product markets as well as the prospects of future promotion on various target markets. Periodically the cluster should audit the TDA and local entities and identify main factors shaping local and regional determinants of the members' activity (tourism and investment attractiveness of the local market, determinants of cooperation between enterprises, possible role of the local government in the development of the local tourism product, 
local entrepreneurship stimulation on the tourism ground and in other industries).

There are plenty of institutions in Poland aimed at the initialization and reinforcement of regional and local innovativeness: business incubators, technological centers, science and technology parks, business support centers, entrepreneurship clubs, technology/innovation transfer centers etc. Cluster does not emerge spontaneously and several policy initiatives to promote its formalization is to be developed. The regional actors might be not sure about the organizations that can be mediators in the cluster. One of the possible ways to overcome the obstacle is the social network analysis identifying central actors and possible structural holes (Kachniewska, 2012, p. 47).

However, in the field of tourism, RTOs and LTOs seem to be the best choice as their experience in tourism audits and tourism product promotion make them the best coordinators of local initiatives. A good starting point for the tourism cluster formation are information banks (the bank of lodging entities, the bank of tourism offers etc.). They are usually commonly known among SMEs, which are to be perceived as the most important and most numerous element of the tourism value chain.

The relatively new model for cluster-based SME development deserves special attention since the small-sized economy is the most vital segment of each national economy. Making this model operational in the tourism industry, especially in creating the tourism product, is certainly of vital importance. The tourism SMEs in their established willingness for cluster formation can contribute the most to this process, although Poland considerably lags behind other European countries in operationalizing cluster formation in potential activities.

It should also be noted that local enterprises, and above all SMEs, are not fully aware of the role they have in creating and managing local supply, or of the influence they exert on the image of the tourism product, and in turn on a customer's destination experience (Rispoli and Tamma, 1991). Also they are not aware of the importance their interactions have in organizing the tourism product and thus in determining destination competitiveness on the market (Minghetti, 2001, p. 256). From the above premises, it is possible to conclude that SMEs' interaction contributes to the development of a tourism product and a tourist destination, especially if this interaction is the result of a targeted (controlled), rather than a spontaneous consolidation of SMEs. The cluster is considered to be the most suitable form for consolidating SMEs in developing tourism products and destinations.

A cluster requires effective governance in its implementation and consolidation. Cluster actors share similar barriers to external environment 
that can be more easily reduced by coordinated action (Doloreux and Shearmur, 2009). A cluster emerges because there is an institutional context that creates advantages based on the physical proximity and existent social capital. Firms can be more efficient, reacting more quickly than when isolated, work with customers and other firms to develop new products and processes, to reduce the perception of risk and induce trust. Nevertheless clusters can create problems for regional development. The success of a particular cluster can produce an excessive concentration of resources, namely financial resources, creating difficulties for other sectors to develop and produce a type of 'Dutch disease'. The past success of a cluster can also create path dependencies that reduce opportunities for future development and adaptive capacity. The coordinating institution (cluster broker) is required in order to boost the SMEs involvement and sustain their activity in the longer-term.

\section{Conclusion}

Tourism has become an integral component of our lifestyle and thus a global industry, with producers and consumers spread throughout the world. The future trends for tourism seem to suggest that travellers will be especially concerned with not just being "there", but with participating, learning and experiencing the place they visit.

Polish tourism regions (destination areas) seem to be too weak to confront modern tourism expectations. They need an innovative approach and a strict analysis of their tourism potential. The numerical superiority of SMEs in the Polish TDAs makes it extremely difficult to coordinate efforts aimed at cluster formation. Moreover the SMEs anxiety to cooperate (dominance of competitive relations over the cooperative ones), low level of social trust and the reluctance to cooperate with local authorities makes it extremely difficult to start new initiatives. It is worth to consider whether the RTOs and LTOs (although they differ in many aspects form tourism clusters) could be a starting point of the cluster initiative or even the temporary cluster broker.

To sum up it can be stated that:

- RTOs/LTOs can be transformed into the tourism cluster if their members are innovative and entrepreneurial, local authorities display low level of bureaucracy and formalization, and the cooperating institutions represent high knowledge sharing inclination

- The possibility to limit the influence of political factor is a very important determinant of the transformation.

- Cooperation of local entities, irrespective of their motives and reason to form the cluster, will significantly contribute to the creation of integrated and innovative tourism region, positively influencing its competitiveness. 
The Polish Tourism Organisation needs local agendas in order to audit the chance of regional and local cluster formation as well as the future evaluation of cluster member efforts. RTOs and LTOs are natural partners who have already gained some experience in the development of local tourism product and quality improvement of TDAs' offer.

\section{References}

Alcouffe, A., Coulomb, F. (1993). Small and Medium-sized Business in European Tourist Sectors. Paris: OECD.

Artavia, R. (2000). Cluster Dynamics: A New Concern for Managers. INCAE. Augustyn, A. (1998). The road to quality enhancement in Tourism. International Journal of Contemporary Hospitality Management, 10(4), 145-158.

Bieger,T.(1997). ManagementvonDestinationenundTourismusorganisationen. Muenchen, Wien: Oldenbourg.

Buhalis, D. (2000). Marketing the competitive destination of the future. Tourism Management, 21, 97-116.

Burt, R. (1992). Structural Holes: The Social Structure of Competition. Cambridge: Harvard University Press.

Carrie, A. (1999). Integrated clusters - the future basis of competition. International Journal of Agile Management Systems, 1(1), 45-50.

Chen, S. (2010). The research process review of the regional tourism industrial cluster at home and abroad. China Economist, 10, 275-276.

Cooke, P. (2001). Regional innovation systems, clusters, and the knowledge economy. Industrial and Corporate Change, Vol. 10, Number 4, Oxford: Oxford University Press.

Crouch, G.I., Ritchie, B., (2000). The competitive destination: A sustainability perspective. Tourism Management,1, 1-7.

Doloreux, D., Shearmur, R. (2009). Maritime Clusters in diverse regional contexts: The case of Canada. Marine Policy, 33, 520-527.

Dyer, J., Singh, H. (1998). The relational view: cooperative strategy and sources of interorganizational competitive advantage. Academy of Management Review, 23(4).

Enright, M. J., Newton, J. (2005). Determinants of tourism destination competitiveness in Asia Pacific: Comprehensiveness and universality. Journal of Travel Research, 43, 339-350.

Friedman, J., Alonso, W. (1964). Regional Development and Planning: A Reader. Boston: Massachusetts Institute of Technology.

Goetz, M. (2006). Atrakcyjność klastrów dla bezpośrednich inwestycji zagranicznych (BIZ). Zeszyty Naukowe Kolegium Gospodarki Światowej, 20, Warszawa: SGH.

Gorynia, M, Jankowska, B. (2007). Koncepcja klastrów jako sposób regulacji zachowań podmiotów gospodarczych. Ekonomista, 3. 
Grängsjö, Y. F., Gummesson, E. (2006). Hotel networks and social capital in destination marketing. International Journal of Service Industry Management, 17(1), 58-75.

Harrison, B. (1992). Industrial Districts: Old wine in new bottles? Regional Studies, 26, 469-483.

Hjalager, A. M. (2000). Tourism destinations and the concept of industrial districts. Tourism and Hospitality Research, 2(3), 199-213.

Holloway, J.Ch. (1996). The Business of Tourism. London: Pitman.

Inkpen, A. C., Tsang, E. W. K. (2005). Social capital network and knowledge transfer. Academy of Management Review, 30(1), 146-165.

Isard, W. (1956). Location and Space-Economy. Cambridge: MIT Press.

Jackson, J., Murphy, P. (2002). Tourism destinations as clusters: Analytical experiences from the new world. Tourism and Hospitality Research, 4(1), 36-52.

Januszewska, M., Nawrocka, E. (2008). Pobudzanie przedsiębiorczości lokalnej i innowacyjności a konkurencyjność obszaru recepcji turystycznej. In: G. Gołembski (Ed.), Turystyka jako czynnik wzrostu konkurencyjności regionów w dobie globalizacji (pp. 283-292). Poznań: Wyd. Akademii Ekonomicznej w Poznaniu.

Kachniewska, M. (2004). Obszar recepcji turystycznej jako przedmiot kompleksowego zarządzania przez jakość (TQM). In: S. Bosiacki, J. Grell (Eds.), Gospodarka turystyczna w XXI wieku. Szanse i bariery rozwoju w warunkach integracji międzynarodowej. Poznań: AWF w Poznaniu.

Kachniewska, M. (2006a). Tourism Quality Management. Warsaw: WSHiFM.

Kachniewska, M. (2006b). Modele jakości usług a specyfika produktu turystycznego. In: Turystyka w badaniach naukowych. Prace ekonomiczne. Rzeszów: WSliz.

Kachniewska, M. (2009). Uwarunkowania konkurencyjności przedsiębiorstwa hotelowego. Warszawa: Oficyna Wydawnicza SGH.

Kachniewska, M. (2011). Funkcja turystyczna jako determinanta jakości życia na wsi. In: Turystyka wiejska - społeczny wymiar w ekonomicznym kontekście. In: Folia Pomeranae Universitatis Technologiae Stetinensis 288, Oeconomica 64, 53-71.

Kachniewska, M. (2012), . Zastosowanie analizy sieci społecznych w zarządzaniu zrównoważonym rozwojem turystyki miejskiej. In: T. Żabińska (Ed.) Studia Ekonomiczne nr 119, Turystyka na obszarach miejskich. Uwarunkowania rozwoju. Narzędzia promocji (pp. 45 - 59). Katowice: UE w Katowicach.

Lawson, C. (1999). Towards the competence theory of the region. Cambridge Journal of Economics, 23, pp. 151-166.

Liu, Q., Yang, Q. (2013). Research on tourism industrial cluster from the perspective of network platform. Interdisciplinary Journal of Contemporary Research in Business, 4(11), 25-29. 
Malmberg, A., Maskell, P. (1997). Towards and Explanation of Regional specialization and Industry agglomeration. European Planning Studies, 5(1), 25-41.

Marshall, A. (1920). Principles of Economics. London: Macmillan.

Medlik, S., Middleton, V.T.C. (1979). The Product Formulation in Tourism, AIEST Publication.

Minghetti, V. (2001). From destination to destination marketing and management: Designing and repositioning tourism products. The International Journal of Tourism Research, 3.

Nourse, H. O. (1968). Regional Economics. New York: McGraw Hill.

Oliver, C. (1990). Determinants of interorganizational relationships: Integration and future directions. Academy of Management Review, 15(2).

Penrose, E. T. (1959). The Theory of the Growth of the Firm. Oxford: Oxford University Press.

Pereira, E. T., Fernandes, A. J. (2004), The Clusters Development as a Factor of Competitive Advantage In: 2nd International Conference an Enterprise Odyssey - Building Competitive Advantage, Graduate School of Economics \& Bussiness, Zagreb June $17-19,1424-1432$.

Piore, M., Sabel, C. (1984). The Second Industrial Divide, New York: Basic Books.

Porter, M. E. (1980). Competitive Strategy. New York: Free Press.

Porter, M. E. (1990). The Competitive Advantage of Nations. New York: Free Press.

Porter, M. E. (1998). On Competition. Boston: Harvard Business Review Press.

Prahalad, C.K.; Hamel, G. (1990). Core Competence of the Corporation. Harvard Business Review.

Reid, D.G. (2003). Tourism, Globalization and Development, Responsible Tourism Planning. Pluto Press.

Richardson, G. (1972). The organization of industry. Economic Journal, 82, $883-96$.

Richardson, G. B. (2001). Evolution, Structure and Strategy, DRUID working paper (available at www.druid.dk).

Richardson, G. B. (2003). The organization of industry re-visited, paper presented at the DRUID Summer Conference on Creating, sharing and transferring knowledge. The role of Institutions and Organisations, Copenhagen, 12 - 14 June (available at www.druid.dk)

Rispoli, M., Tamma, M. (1991). Le imprese alberghiere. CEDAM, Padua.

Ritchie, B. J. R., Crouch, G. I. (2003). The Competitive Destination: A Sustainable Tourism Perspective. Wallingford, Oxon: CABI Publishing.

Rosenfeld, S. A. (1997). Bringing business clusters into the mainstream of economic development. European Planning Studies, 5(1), 3-23.

Torre, A., Rallet, A. (2005). Proximity and localization. Regional Studies, 39, 47-59. 
Weaver, D., Oppermann, M. (2000). Tourism Management. Wiley, Milton.

Williamson, O. E. (1975). Markets and hierarchies: Analysis and antitrust implications. A Study in the Economics of International Organizations. New York: Free Press.

Yimei, Y., Yulin, L., Zhigao, L. (2004). Tourism enterprise cluster: New strategic model to enhance destination competitiveness. Fujian Tribune (A Literature, history \& Philosophy Bimonthly), 8(22).

\section{Abstrakt (in Polish)}

Strategia rozwoju i wzmocnienia konkurencyjności obszarów recepcji turystycznej coraz częściej odwołuje się do koncepcji tworzenia klastra turystycznego. Watek ten stał się także tematem wiodqcym prac Polskiej Organizacji Turystycznej, wdrażajqcej nowy program komercjalizacji polskiej oferty turystycznej oraz wsparcia procesu integracji (poziomej i pionowej) MSP turystycznych, ukierunkowany na wzmocnienie innowacyjności polskich regionów i przedsiębiorstw turystycznych. Głównym celem artykułu jest wskazanie uzasadnienia dla koncepcji tworzenia klastrów turystycznych w polskich warunkach, sformułowanie głównych cech klastra turystycznego oraz ich zestawienie z cechami działajqcych w Polsce regionalnych i lokalnych organizacji turystycznych, które mogłyby stanowić punkt wyjścia dla tworzenia nowoczesnych struktur klastrowych w polskiej turystyce. Zagadnienie wpływu klastrów na efektywność MSP oraz konkurencyjność obszarów recepcji turystycznej odniesiono do dokonań teorii ekonomii.

Słowa kluczowe: klaster turystyczny, definicja, sieć współpracy, konkurencyjność, obszar recepcji turystycznej. 